\title{
Streptomyces hyderabadensis sp. nov., an actinomycete isolated from soil
}

\author{
Correspondence \\ T. V. K. Reddy \\ reddykishoretv@gmail.com
}

\author{
T. V. K. Reddy, ${ }^{1}$ Shaik Mahmood, ${ }^{1}$ Laskaris Paris, ${ }^{2}$ Y. Harish \\ Kumar Reddy, ${ }^{3}$ E. M. H. Wellington ${ }^{2}$ and M. Mohammed Idris ${ }^{4}$ \\ ${ }^{1}$ Microbiology Laboratory, Department of Botany, University College of Science, Osmania University, \\ Hyderabad, 500007, India \\ ${ }^{2}$ Department of Biological Sciences, University of Warwick, Gibbet Hill Road, Coventry CV4 7AL, \\ UK \\ ${ }^{3}$ Department of Microbiology, University College of Science, Osmania University, Hyderabad, \\ 500007, India \\ ${ }^{4}$ Centre for Cellular and Molecular Biology, Uppal road, Hyderabad 500007, India
}

\begin{abstract}
A novel actinomycete, designated strain $\mathrm{OU}-40^{\top}$, was isolated from farm soil collected from the Hyderabad region of Andhra Pradesh, southern India. The strain was found to have morphological and chemotaxonomic characteristics typical of species of the genus Streptomyces. Phylogenetic analysis based on $16 \mathrm{~S}$ rRNA gene sequences indicated that strain $\mathrm{OU}-40^{\top}$ belonged to the genus Streptomyces, and was related most closely to Streptomyces pactum NBRC $13433^{\top}$ (99.0\% sequence similarity), Streptomyces olivaceus NBRC $12805^{\top}$ (99.0\%) and Streptomyces parvulus NBRC $13193^{\top}$ ( $\left.98.8 \%\right)$. Strain OU $-40^{\top}$ could be distinguished from the type strains of its closest phylogenetic relatives based on levels of DNA-DNA relatedness and comparison of morphological and phenotypic data. It is therefore concluded that strain $\mathrm{OU}-40^{\top}$ represents a novel species of the genus Streptomyces, for which the name Streptomyces hyderabadensis sp.

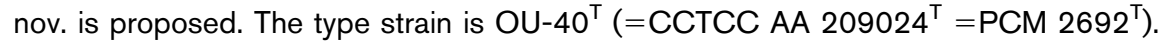

The genus Streptomyces was proposed by Waksman \& Henrici (1943) to accommodate aerobic, spore-forming actinomycetes. At the time of writing, the genus comprises nearly 550 recognized species (Euzéby, 2009). Most species of the genus Streptomyces are able to form an extensively branched substrate mycelium and are also able to produce aerial hyphae that typically differentiate into chains of spores. Species of the genus Streptomyces have LLdiaminopimelic acid in the cell-wall peptidoglycan but no characteristic sugars (wall chemotype I sensu Lechevalier \& Lechevalier, 1970), and possess DNA rich in G+C (Williams et al., 1983; Manfio et al., 1995). The streptomycetes, producers of more than half of the 10000 documented bioactive compounds, such as antibiotics, enzymes, inhibitors and pharmacologically active agents, have offered over 50 years of interest to industry and academia (Anderson \& Wellington, 2001; Berdy, 2005). During the course of our screening programme for antibiotics, strain OU $-40^{\mathrm{T}}$ was isolated from a soil sample collected from farm soil, Hyderabad region, Andhra Pradesh, southern India, and was provisionally assigned to the genus Streptomyces based on its chemotaxonomic

The GenBank/EMBL/DDBJ accession number for the 16S rRNA gene sequence of strain $\mathrm{OU}-40^{\top}$ is $\mathrm{FM} 998652$. and morphological properties. A polyphasic taxonomic investigation based on a combination of phenotypic and genotypic characteristics revealed that strain $\mathrm{OU}-40^{\mathrm{T}}$ represents a novel species of the genus Streptomyces.

Strain OU $-40^{\mathrm{T}}$ was isolated by using a modified protocol developed by Atalan et al. (2000) on actinomycetes isolation agar (HiMedia) supplemented with cycloheximide $\left(50 \mu \mathrm{g} \mathrm{ml}^{-1}\right)$ and nystatin $\left(25 \mu \mathrm{g} \mathrm{ml}^{-1}\right)$. The agar was seeded with the soil suspension and incubated at $28{ }^{\circ} \mathrm{C}$ for 14 days (Olson, 1968). The isolate was maintained on oatmeal agar slants (International Streptomyces Project medium 3, ISP 3 ) at $4{ }^{\circ} \mathrm{C}$ and as glycerol suspensions $(20 \%, v / v)$ at $-20{ }^{\circ} \mathrm{C}$.

The morphological characteristics of strain $\mathrm{OU}-40^{\mathrm{T}}$ were examined by light and scanning electron microscopy of 21-day-old cultures on oatmeal agar (Williams \& Davies, 1967). The coverslip technique (Zhou et al., 1998; Kawato \& Shinobu, 1959) was used to observe hyphae and spore chain morphology by light microscopy. Spore chain morphology and spore surface ornamentation were studied by examining gold-coated dehydrated specimens with a Jeol model JSM 5600 scanning electron microscope. Cultural characteristics were observed on a number of agar media following incubation at $28{ }^{\circ} \mathrm{C}$ for 14 days. 
Strain OU $-40^{\mathrm{T}}$ was examined for a range of physiological and biochemical properties as described by Shirling \& Gottlieb (1966) and Williams et al. (1983). Colony colour was determined with reference to Kelly (1964).

Cells for most of the chemotaxonomic studies were obtained after incubation at $28{ }^{\circ} \mathrm{C}$ for 1 week in shake flasks of ISP 2 broth. The isomer of diaminopimelic acid and whole-cell sugars were analysed following the procedures developed by Hasegawa et al. (1983) and Lechevalier \& Lechevalier (1980). Menaquinones were extracted and purified according to Collins (1985) and were analysed by HPLC. Analyses of fatty acids were performed by GC by using the transmethylation technique described by Lepage \& Roy (1984). The isolate was grown for 7 days with shaking at $28{ }^{\circ} \mathrm{C}$ in modified Bennett's broth, both the supernatant and mycelial mass of a culture were extracted with ethyl acetate and acetone, and antimicrobial activity was determined via the paper disc diffusion method (Bauer et al., 1966).

The genomic DNA of strain OU $-40^{\mathrm{T}}$ was isolated by using the Kirby extraction method as described by Kieser et al. (2000). Amplification of the 16S rRNA gene was carried out as described by Edwards et al. (1989). Pairwise sequence similarities were calculated by using a global alignment algorithm, which was implemented with the EzTaxon server (Chun et al., 2007). Phylogenetic analyses were performed by using the software package MEGA 4.0 (Tamura et al., 2007) after multiple alignment of the sequence data with CLUSTAL_x (Thompson et al., 1997). Distances were calculated by using distance options according to Jukes \& Cantor (1969) and clustering was performed by using the neighbour-joining method (Saitou \& Nei, 1987). Minimum-evolution (Rzhetsky \& Nei, 1992) and maximum-parsimony (Eck \& Dayhoff, 1966) trees were generated by means of methods contained within the MEGA 4.0 software package. Bootstrap analyses were used to evaluate the tree topology based on 1000 resamplings (Felsenstein, 1985). The DNA G + C content of strain OU$40^{\mathrm{T}}$ was determined by using the thermal denaturation method (Mandel \& Marmur, 1968).

DNA-DNA hybridization experiments were conducted by using the dot-blot hybridization method (Chung et al., 1999) and a simple fluorimetric method was used to estimate levels of DNA-DNA relatedness based on thermal denaturation temperatures (Gonzalez \& Saiz-Jimenez, 2005; Reddy et al., 2010). Genomic DNA (200 and $400 \mathrm{ng}$ as homoduplex and heteroduplex DNA, respectively) was used for melting curve analysis in a $10 \mu \mathrm{l}$ reaction volume with a final $1 \times$ concentration of SYBR green. Analyses of the melting curves were performed by using $10 \mathrm{~min}$ initial denaturation and $5 \mathrm{~min}$ renaturation, followed by melting curve analysis from 20 to $90{ }^{\circ} \mathrm{C}$ (ramping at $2{ }^{\circ} \mathrm{C} \mathrm{min}^{-1}$ ). Melting curve analyses were performed in triplicate. $\Delta T_{\mathrm{m}}$ values between homologous and hybrid DNA of $5{ }^{\circ} \mathrm{C}$ or higher were considered as corresponding to distinct microbial species.
The chemical and morphological properties of strain OU$40^{\mathrm{T}}$ were consistent with its assignment to the genus Streptomyces (Williams et al., 1989; Manfio et al., 1995). The strain formed extensively branched substrate mycelia and aerial hyphae which carried smooth-surfaced oval spores in long straight chains (Fig. 1). The cultural characteristics of strain $\mathrm{OU}-40^{\mathrm{T}}$ on various standard media are given in Table 1. The aerial mycelium of strain OU- $40^{\mathrm{T}}$ varied from white to grey on different media, and substrate mycelium from brown to light yellow. No diffusible pigments were produced and no melanin was observed on peptone yeast extract iron agar or tyrosine agar.

The strain contained LL-diaminopimelic acid in the peptidoglycan of the cell wall and no characteristic sugars, indicating that it exhibits wall chemotype I (Lechevalier \& Lechevalier, 1970). It contained MK-9 $\left(\mathrm{H}_{6}, 68 \% ; \mathrm{H}_{8}, 21 \%\right.$; $\left.\mathrm{H}_{4}, 11 \%\right)$ as the predominant isoprenologues. The major fatty acids were iso- $\mathrm{C}_{16: 0}(17 \%)$, iso- $\mathrm{C}_{15: 0}(19 \%)$, iso$\mathrm{C}_{17: 0}(15 \%)$, anteiso- $\mathrm{C}_{15: 0}(14 \%)$, anteiso- $\mathrm{C}_{17: 0}(9 \%)$, $\mathrm{C}_{16: 0}(8 \%)$ and iso- $\mathrm{C}_{14: 0}(5 \%)$, a profile that is consistent with those for species of the genus Streptomyces. The G +C content of the DNA of strain OU- $40^{\mathrm{T}}$ was $70.2 \mathrm{~mol} \%$.
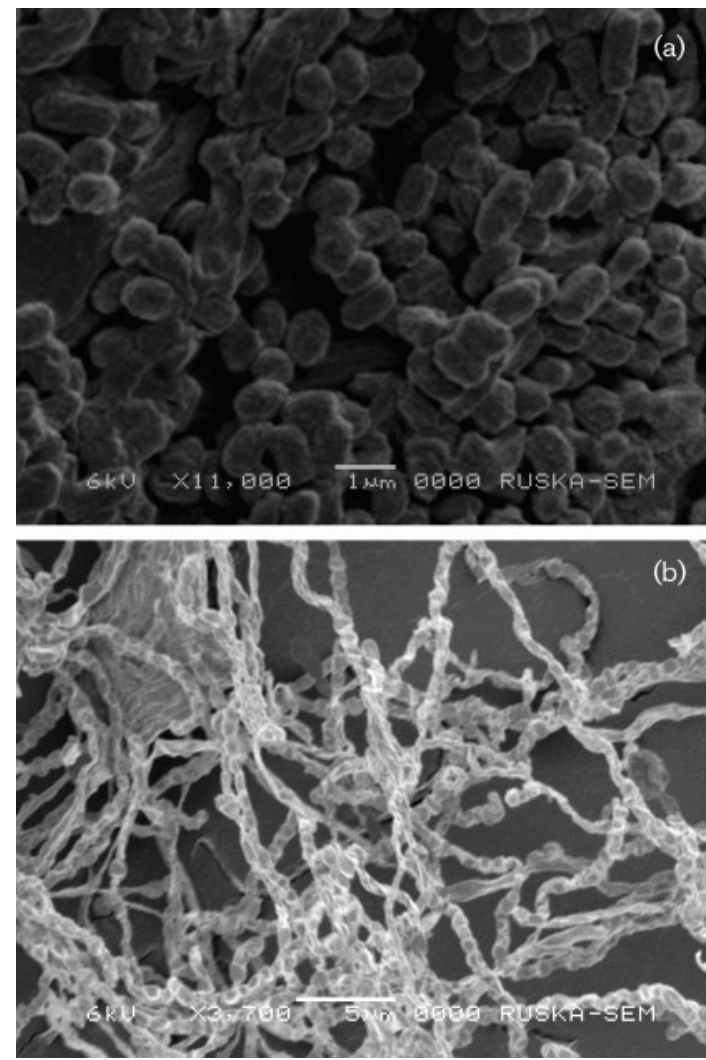

Fig. 1. Scanning electron micrographs showing the morphology of cells of strain $\mathrm{OU}-40^{\top}$ grown on oatmeal agar for 21 days at $28{ }^{\circ} \mathrm{C}$. (a) Smooth oval-shaped spores; bar, $1 \mu \mathrm{m}$. (b) Long straight chains; bar, $5 \mu \mathrm{m}$. 
Table 1. Growth and cultural characteristics of strain $\mathrm{OU}-40^{\top}$

+++ , Good growth; ++ , moderate growth; + , poor growth.

\begin{tabular}{|lcll|}
\hline \multirow{2}{*}{ Agar medium } & Growth & \multicolumn{2}{c|}{ Colour of mycelium } \\
\cline { 2 - 4 } & & Aerial & Substrate \\
\hline Yeast extract malt extract & +++ & Grey & Brown \\
(ISP 2) & & & \\
Oatmeal (ISP 3) & ++ & Grey/white & Brown \\
Inorganic salts/starch (ISP 4) & +++ & Grey & Pale yellow \\
Glycerol/asparagine (ISP 5) & ++ & Dark grey & Light yellow \\
Tyrosine (ISP 7) & ++ & Grey & Light brown \\
Czapek-Dox & ++ & Whitish grey & Brown \\
Nutrient agar & + & White & Light yellow \\
Modified Bennett's & +++ & Grey & Yellow \\
& & & \\
\hline
\end{tabular}

The phenotypic characteristics of strain OU $-40^{\mathrm{T}}$ were also consistent with its placement in the genus Streptomyces. An almost-complete $16 \mathrm{~S}$ rRNA gene sequence of strain OU- $40^{\mathrm{T}}$ (1402 nt) was determined in this study. A phylogenetic tree was reconstructed based on 16S rRNA gene sequences to show the relationship between strain $\mathrm{OU}-40^{\mathrm{T}}$ and related species of the genus Streptomyces (Fig. 2). Strain OU-40 formed a distinct phyletic line together with the type strains of Streptomyces pactum, Streptomyces parvulus and Streptomyces olivaceus. Strain OU- $40^{\mathrm{T}}$ shared highest $16 \mathrm{~S}$ rRNA gene sequence similarity with Streptomyces pactum NBRC $13433^{\mathrm{T}}(99.0 \%)$, Streptomyces olivaceus NBRC $12805^{\mathrm{T}}(99.0 \%)$, which corresponds to $14 \mathrm{nt}$ differences out of 1402, and $98.8 \%$ similarity with Streptomyces parvulus NBRC $13193^{\mathrm{T}}$ (16 nt differences out of 1402). Differential phenotypic characteristics between strain OU$40^{\mathrm{T}}$ and its closest phylogenetic relatives are given in Table 2 .

DNA-DNA hybridization experiments were carried out between strain OU-40 ${ }^{\mathrm{T}}$ and $S$. parvulus NBRC $13193^{\mathrm{T}}$, S. pactum NBRC $13433^{\mathrm{T}}$ and S. olivaceus NBRC $12805^{\mathrm{T}}$. Mean $( \pm \mathrm{sD})$ levels of DNA-DNA relatedness between strain OU$40^{\mathrm{T}}$ and the type strains of $S$. parvulus, S. pactum and $S$. olivaceus were $40 \pm 1.2,35.6 \pm 0.8$ and $25 \pm 1.6 \%$, respectively, significantly lower than the $70 \%$ recommended cutoff for recognition of a genomic species (Wayne et al., 1987). The $\Delta T_{\mathrm{m}}$ values obtained via the thermal denaturation method between the homologous ( $S$. parvulus NBRC $13193^{\mathrm{T}}$, S. pactum NBRC $13433^{\mathrm{T}}$, S. olivaceus NBRC $12805^{\mathrm{T}}$ ) and hybrid (strain OU-40 ${ }^{\mathrm{T}}$ with $S$. parvulus NBRC $13193^{\mathrm{T}}$, OU $-40^{\mathrm{T}}$ with S. pactum NBRC $13433^{\mathrm{T}}$ and OU- $40^{\mathrm{T}}$ with $S$. olivaceus NBRC $12805^{\mathrm{T}}$ ) DNA were 10,8 and $7.5^{\circ} \mathrm{C}$, respectively. A $\Delta T_{\mathrm{m}}$ value of $5{ }^{\circ} \mathrm{C}$ or higher is considered to indicate separate bacterial species (Anderson \& Wellington, 2001; Wayne et al., 1987; Rossello-Mora \& Amann, 2001), and thus these data corroborate the findings of dot-blot analysis. Based on the genotypic and phenotypic evidence presented, strain OU- $40^{\mathrm{T}}$ is considered to represent a novel species of the genus Streptomyces, for which the name Streptomyces hyderabadensis sp. nov. is proposed.

\section{Description of Streptomyces hyderabadensis sp. nov.}

Streptomyces hyderabadensis (hy.de.ra.bad.en'sis. N.L. masc. adj. hyderabadensis pertaining to the Hyderabad

\footnotetext{
${ }^{*} 100$ Streptomyces flavoviridis NBRC 12772 ${ }^{\top}$ (AB184842)

40 Streptomyces pilosus NBRC $12807^{\top}$ (AB184161)

Streptomyces atrovirens NRRL B-16357' (DQ026672)

Streptomyces viridodiastaticus NBRC $13106^{\top}$ (AB184317)

" 100 Streptomyces albogriseolus NRRL B-1305' (AJ494865)

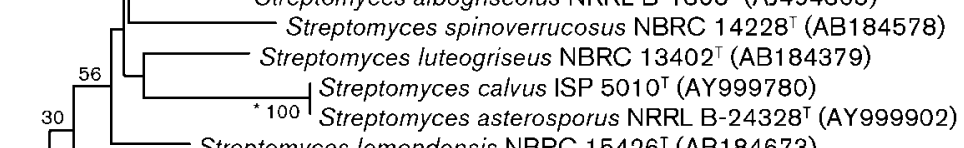

*46 Streptomyces lomondensis NBRC 15426 ${ }^{\top}$ (AB184673)

*46 Streptomyces parvulus NBRC 13193' (AB184326)

Strain OU-40 ${ }^{\top}$ (FM998652)

Streptomyces pactum NBRC 13433 (AB184398)

${ }^{*} 100$ Streptomyces olivaceus NBRC $12805^{\top}$ (AB249920)

- Streptomyces malachitospinus NBRC $101004^{\top}$ (AB249954)

46 [Streptomyces tendae ATCC $19812^{\top}$ (D63873)

*54 Streptomyces tritolerans DAS $165^{\top}$ (DQ345779)

Streptomyces violaceorubidus LMG $20319^{\top}$ (AJ781374)

*84 Streptomyces aurantiogriseus NRRL B-5416 ${ }^{\top}$ (AY999773)

88 Streptomyces lienomycini LMG $20091^{\top}$ (AJ781353)

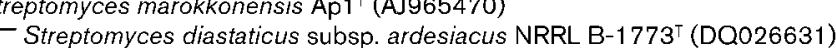

41 Streptomyces rubrogriseus LMG 20318 ${ }^{\top}$ (AJ781373)

"66 Streptomyces violaceolatus DSM 40438 ${ }^{\top}$ (AF503497)

73 Streptomyces humiferus DSM $43030^{\top}$ (AF503491)

- Streptomyces violaceoruber NBRC $12826^{\top}$ (AB184174)

88 Streptomyces coelescens DSM 40421 ${ }^{\top}$ (AF503496)

61 Streptomyces tricolor NBRC $15461^{\top}$ (AB184687)

Streptomyces anthocyanicus NBRC $14892^{\top}$ (AB184631)

Streptomyces cacaoi subsp. cacaoi KCTC $9758^{\top}$ (AY999819)

Fig. 2. Unrooted neighbour-joining tree (Saitou \& Nei, 1987) based on 16S rRNA gene sequences showing the phylogenetic positions of strain $\mathrm{OU}-40^{\top}$ and the type strains of related species of the genus Streptomyces. Asterisks indicate branches that were also found by using the minimum-evolution (Rzhetsky \& Nei, 1992) and maximum-parsimony (Eck \& Dayhoff, 1966) tree-making algorithms. Numbers at nodes are bootstrap percentages based on a neighbour-joining analysis of 1000 resampled datasets; only values $\geqslant 30 \%$ are shown. Bar, 0.01 substitutions per nucleotide position. 
Table 2. Differential phenotypic characteristics between strain $\mathrm{OU}-40^{\top}$ and its closest phylogenetic relatives in the genus Streptomyces

Strains: 1 , OU $-40^{\mathrm{T}}$; 2, S. pactum NBRC $13433^{\mathrm{T}}$; 3, S. olivaceus NBRC $12805^{\mathrm{T}}$; 4, S. parvulus NBRC $13193^{\mathrm{T}}$. All data are from the present study.

\begin{tabular}{|c|c|c|c|c|}
\hline Characteristic & 1 & 2 & 3 & 4 \\
\hline Spore-chain morphology & Straight & Spirales & Rectiflexibiles & Spirales \\
\hline Spore surface & Smooth & Hairy & Smooth & Smooth \\
\hline $\begin{array}{l}\text { Production of diffusible } \\
\text { pigments }\end{array}$ & - & + & - & + \\
\hline \multicolumn{5}{|l|}{ Degradation of: } \\
\hline Casein & - & + & + & + \\
\hline DNA & - & + & - & + \\
\hline \multicolumn{5}{|c|}{ Utilization of carbon sources } \\
\hline L-Arabinose & + & - & + & + \\
\hline Fructose & - & + & + & + \\
\hline Rhamnose & + & - & + & + \\
\hline Raffinose & - & - & + & - \\
\hline Sucrose & + & + & - & + \\
\hline Xylose & + & - & + & - \\
\hline Lactose & + & - & + & + \\
\hline \multicolumn{5}{|c|}{ Utilization of nitrogen sources } \\
\hline Cysteine & + & - & + & - \\
\hline Isoleucine & + & + & - & + \\
\hline Glycine & + & + & - & - \\
\hline \multicolumn{5}{|l|}{ Growth at/with: } \\
\hline $45^{\circ} \mathrm{C}$ & - & - & - & + \\
\hline $7 \% \mathrm{NaCl}$ & - & - & + & + \\
\hline pH 5 & - & + & + & - \\
\hline $\mathrm{pH} 11$ & + & + & - & + \\
\hline
\end{tabular}

region of Andhra Pradesh, southern India, from where the type strain was isolated).

Aerobic, Gram-positive actinomycete that forms an extensively branched substrate mycelium and aerial hyphae that differentiate into long straight spore chains. Spores are oval in shape with smooth surfaces. A brown substrate mycelium and a grey aerial spore mass are formed on glucose-yeast extract/malt agar (ISP 2). Melanin pigments are not produced on peptone yeast extract/iron agar or tyrosine agar, and no diffusible pigment is produced on all media tested. Growth occurs well at 20 and $37{ }^{\circ} \mathrm{C}$ but not at $10{ }^{\circ} \mathrm{C}$. Grows at $\mathrm{pH} 6-11$ and in the presence of $5 \%$ $\mathrm{NaCl}$. Metabolizes hypoxanthine, tyrosine, urea, xanthine, gelatin, guanine, starch and Tween 80 but not casein, DNA, xylan or keratin. Galactose, glucose, mannitol, mannose, raffinose, arabinose, xylose, ribose, cellobiose, lactose, sucrose, maltose, trehalose, sodium acetate, sodium succinate and sodium pyruvate are used as sole carbon sources for energy and growth, but not fructose, rhamnose or cellulose. Proline, cysteine, histidine, phenylalanine, isoleucine and glycine are metabolized as sole nitrogen sources. Growth occurs in the presence of penicillin G $\left(10 \mathrm{IU} \mathrm{ml}^{-1}\right)$, rifampicin $\left(50 \mu \mathrm{g} \mathrm{ml}^{-1}\right)$ and ampicillin $\left(30 \mu \mathrm{g} \mathrm{ml}^{-1}\right)$, but not in the presence of streptomycin $\left(50 \mu \mathrm{g} \mathrm{ml}^{-1}\right)$, kanamycin $\left(30 \mu \mathrm{g} \mathrm{ml}^{-1}\right)$ or novamycin $\left(30 \mu \mathrm{g} \mathrm{ml}^{-1}\right)$. The predominant menaquinones are MK-9
$\left(\mathrm{H}_{6}, 68 \% ; \mathrm{H}_{8}, 21 \% ; \mathrm{H}_{4}, 11 \%\right)$. The major fatty acids are iso- $\mathrm{C}_{16: 0}$, iso- $\mathrm{C}_{15: 0}$, iso- $\mathrm{C}_{17: 0}$, anteiso- $\mathrm{C}_{15: 0}$, anteiso$\mathrm{C}_{17: 0}, \mathrm{C}_{16: 0}$ and iso- $\mathrm{C}_{14: 0}$. Active against plant pathogenic moulds Aspergillus niger, Aspergillus flavus and Fusarium oxysporum and also against bacteria Escherichia coli, Pseudomonas aeruginosa, Staphylococcus aureus and Bacillus subtilis. The genomic DNA G $+\mathrm{C}$ content of the type strain is $70.2 \mathrm{~mol} \%$.

The type strain, OU $-40^{\mathrm{T}}\left(=\mathrm{CCTCC}\right.$ AA $209024^{\mathrm{T}}=\mathrm{PCM}$ $2692^{\mathrm{T}}$ ), was isolated from farm soil collected from the Hyderabad region of Andhra Pradesh, southern India.

\section{Acknowledgements}

We are grateful to Professor Dr D. P. Labeda for providing the $S$. parvulus culture and Mr Ravi Kumar (Indian Institute of Chemical Technology, Hyderabad) for his assistance with fatty acid and menaquinone analyses. We are also grateful to $\mathrm{Dr}$ Slawomir Ciesielski, University of Warmia and Mazury in Olsztyn, Poland, for deposition of the type strain. T.V.K. R. thanks the University Grant Commission (UGC), Government of India, for providing a fellowship.

\section{References}

Anderson, A. S. \& Wellington, E. M. H. (2001). The taxonomy of Streptomyces and related genera. Int J Syst Evol Microbiol 51, 797-814. 
Atalan, E., Manfio, G. P., Ward, A. C., Kroppenstedt, R. M. \& Goodfellow, M. (2000). Biosystematic studies on novel streptomycetes from soil. Antonie van Leeuwenhoek 77, 337-353.

Bauer, A. W., Kirby, M. D. K., Sherris, J. C. \& Turck, M. (1966). Antibiotic susceptibility testing by standard single disc diffusion method. Am J Clin Pathol 45, 493-496.

Berdy, J. (2005). Bioactive microbial metabolites. J Antibiot 58, 1-26. Chun, J., Lee, J.-H., Jung, Y., Kim, M., Kim, S., Kim, B. K. \& Lim, Y.-W. (2007). EzTaxon: a web-based tool for the identification of prokaryotes based on $16 \mathrm{~S}$ ribosomal RNA gene sequences. Int J Syst Evol Microbiol 57, 2259-2261.

Chung, Y. R., Sung, K. C., Mo, H. K., Son, D. Y., Nam, J. S., Chun, J. S. \& Bae, K. S. (1999). Kitasatospora cheerisanensis sp. nov., a new species of the genus Kitasatospora that produces an antifungal agent. Int J Syst Bacteriol 49, 753-758.

Collins, M. D. (1985). Isoprenoid quinine analysis in classification and identification. In Chemical Methods in Bacterial Systematics, pp. 267287. Edited by M. Goodfellow \& D. E. Minnikin. London: Academic Press.

Eck, R. V. \& Dayhoff, M. O. (1966). Atlas of Protein Sequence and Structure. Silver Springs, MD: National Biomedical Research Foundation.

Edwards, U., Rogall, T., Blockerl, H., Emde, M. \& Bottger, E. C. (1989). Isolation and direct complete nucleotide determination of entire genes. Characterization of a gene coding for 16S ribosomal RNA. Nucleic Acids Res 17, 7843-7853.

Euzéby, J. (2009). List of Prokaryotic names with Standing in Nomenclature (http://www.bacterio.cict.fr/).

Felsenstein, J. (1985). Confidence limits on phylogenies: an approach using the bootstrap. Evolution 39, 783-791.

Gonzalez, J. M. \& Saiz-Jimenez, C. (2005). A simple fluorimetric method for the estimation of DNA-DNA relatedness between closely related microorganisms by thermal denaturation temperatures. Extremophiles 9, 75-79.

Hasegawa, T., Takizawa, M. \& Tanida, S. (1983). A rapid analysis for chemical grouping of aerobic actinomycetes. J Gen Appl Microbiol 29, 319-322.

Jukes, T. H. \& Cantor, C. R. (1969). Evolution of protein molecules. In Mammalian Protein Metabolism, vol. 3, pp. 21-132. Edited by $\mathrm{H}$. N. Munro. New York: Academic Press.

Kawato, M. \& Shinobu, R. (1959). On Streptomyces herbaricolor sp. nov., supplement: a single technique for microscopical observation. Mem Osaka Unit Lib Arts Educ b Nat Sci 8, 114-119.

Kelly, K. L. (1964). Inter-Society Color Council - National Bureau of Standards Color Name Charts Illustrated with Centroid Colors. Washington, DC: US Government Printing Office.

Kieser, T., Bibb, M. J., Buttner, M. J., Charter, K. F. \& Hopwood, D. A. (2000). Practical Streptomyces Genetics. Norwich: The John Innes Foundation.

Lechevalier, M. P. \& Lechevalier, H. (1970). Chemical composition as a criterion in the classification of aerobic actinomycetes. Int J Syst Bacteriol 20, 435-443.

Lechevalier, M. P. \& Lechevalier, H. A. (1980). The chemotaxonomy of actinomycetes. In Actinomycete Taxonomy, pp. 227-291. Edited by
A. Dietz \& D. W. Thayer. Arlington, VA: Society for Industrial Microbiology.

Lepage, G. \& Roy, C. C. (1984). Improved recovery of fatty acid through direct transesterification without prior extraction or purification. J Lipid Res 25, 1391-1396.

Mandel, M. \& Marmur, J. (1968). Use of ultraviolet absorbancetemperature profile for determining the guanine plus cytosine content of DNA. Methods Enzymol 12B, 195-206.

Manfio, G. P., Zakrzewska-Czerwinska, J., Atalan, E. \& Goodfellow, M. (1995). Towards minimal standards for the description of Streptomyces species. Biotechnologiia 8, 228-237.

Olson, E. H. (1968). Actinomycetes Isolation Agar. Supplementary literature. Detroit, MI: Difco Laboratories.

Reddy, T. V. K., Mahmood, S. K., Idris, M. M. \& Ciesielski, S. (2010). Streptomyces osmaniensis sp. nov., a novel streptomycete from soil in south India. Int J Syst Evol Microbiol 60, 1755-1759.

Rosselló-Mora, R. \& Amann, R. (2001). The species concept for prokaryotes. FEMS Microbiol Rev 25, 39-67.

Rzhetsky, A. \& Nei, M. (1992). A simple method for estimating and testing minimum evolution trees. Mol Biol Evol 9, 945-967.

Saitou, N. \& Nei, M. (1987). The neighbor-joining method: a new method for reconstructing phylogenetic trees. Mol Biol Evol 4, 406425.

Shirling, E. B. \& Gottlieb, D. (1966). Methods for characterization of Streptomyces species. Int J Syst Bacteriol 16, 313-340.

Tamura, K., Dudley, J., Nei, M. \& Kumar, S. (2007). MEGA4: molecular evolutionary genetic analysis (MEGA) software version 4.0. Mol Biol Evol 24, 1596-1599.

Thompson, J. D., Gibson, T. J., Plewniak, F., Jeanmougin, F. \& Higgins, D. G. (1997). The CLUSTAL $\mathrm{X}$ windows interface: flexible strategies for multiple sequence alignment aided by quality analysis tools. Nucleic Acids Res 25, 4876-4882.

Waksman, S. A. \& Henrici, A. T. (1943). The nomenclature and classification of the actinomycetes. J Bacteriol 46, 337-341.

Wayne, L. G., Brenner, D. J., Colwell, R. R., Grimont, P. A. D., Kandler, O., Krichevsky, M. I., Moore, L. H., Moore, W. E. C., Murray, R. G. E. \& other authors (1987). International Committee on Systematic Bacteriology. Report of the ad hoc committee on reconciliation of approaches to bacterial systematics. Int J Syst Bacteriol 37, 463-464.

Williams, S. T. \& Davies, F. L. (1967). Use of scanning electron microscope for the examination of actinomycetes. J Gen Microbiol 48, 171-177.

Williams, S. T., Goodfellow, M., Alderson, G., Wellington, E. M. H., Sneath, P. H. A. \& Sackin, M. J. (1983). Numerical classification of Streptomyces and related genera. J Gen Microbiol 129, 1743-1813.

Williams, S. T., Goodfellow, M. \& Alderson, G. (1989). Genus Streptomyces Waksman and Henrici 1943, 339 ${ }^{\mathrm{AL}}$. In Bergey's Manual of Systematic Bacteriology, vol. 4, pp. 2452-2492. Edited by S. T. Williams, M. E. Sharpe \& J. G. Holt. Baltimore: Williams \& Wilkins.

Zhou, Z.-H., Liu, Z.-H., Qiao, Y.-D., Kim, S. B. \& Goodfellow, M. (1998). Saccharopolyspora spinosporotrichia sp. nov., a novel actinomycete from soil. Int J Syst Bacteriol 48, 53-58. 